\title{
O polêmico relatório da Organização Mundial de Saúde
}

O Relatório Mundial da Saúde para o Ano 2000, da Organização Mundial da Saúde (OMS), apresenta uma classificação dos 191 países membros, com base em um novo índice composto (overall health system perfomance), desenvolvido para monitorar o desempenho dos sistemas de saúde em cada país. O índice representa uma média ponderada de indicadores que pretendem medir resultados em relação ao nível de saúde da população (disability-adjusted life expectancy at birth - DALE), a aspectos não-médicos da provisão de serviços (responsiveness) e à justiça no financiamento (fairness of financial contribution).

Avaliar sistemas de saúde não é tarefa simples, principalmente quando o objetivo é comparar realidades distintas, como os sistemas dos países membros e a recente contribuição da OMS é bastante criticável. Utilizou um índice de desempenho novo e complexo, mas que, foi desenvolvido de forma hermética e não compartilhada com os países membros, sem que as bases conceituais e metodológicas deste estivessem acessíveis até a data da divulgação dos resultados. O relatório tem como referência um modelo particular de sistema de saúde, o qual questiona as políticas de saúde universalistas, consideradas de baixa efetividade. Tal abordagem distancia-se da orientação política de vários sistemas de saúde, particularmente daquela adotada pelo sistema de saúde brasileiro (SUS), que se pauta pelo princípio da universalidade no acesso aos serviços de saúde.

As críticas à avaliação realizada tornam-se mais graves à medida que se analisa em detalhe a metodologia empregada. Destacamos a seguir algumas destas críticas apresentadas por pesquisadores da Fundação Oswaldo Cruz em documento técnico (veja o relatório completo no site http://www.ensp.fiocruz.br/deptos/cedoc/Informe/textos/omsfinal.rtf).

As desigualdades em saúde foram calculadas pela fórmula que mede diferenças entre os indivíduos em relação ao valor médio do DALE na população. Dessa forma, pode detectar diferenças, mas não é capaz de indicar quais os grupos sociais que apresentam as piores condições de saúde. Por outro lado, além de o DALE ser um indicador de difícil medição, foi estimado, para grande parte dos países, com base em variáveis sócio-econômicas. A abordagem adotada concentra seu foco nas desigualdades que são associadas às condições de saúde, porém não considera a eqüidade que pode resultar do funcionamento dos sistemas de saúde. Na verdade, o índice composto não mede se a população tem suas necessidades de saúdes atendidas, ao não incluir nenhum indicador de utilização de serviços. Assim, um mesmo país pode apresentar um bom desempenho no índice e, ao mesmo tempo, exibir marcadas desigualdades na utilização e na qualidade dos serviços de saúde.

A avaliação da "responsividade", baseou-se em avaliações de informantes qualificados em apenas 35 países, sendo estas utilizadas para estimar o indicador nos demais países, colocando em questão a validade deste indicador. A medida de justiça na participação das famílias no financiamento do sistema também mostrou-se limitada para apreender as particularidades de cada país. No caso do Brasil, impostos potencialmente progressivos não foram considerados.

O que deveria representar uma contribuição e incentivo à melhoria dos sistemas de saúde dos países resultou em descrédito e repúdio de vários países às estratégias adotadas no Relatório 2000. Assim entenderam, também, os Ministros da Saúde das Américas, reunidos na 42a Reunião do Conselho Diretor das OPS, realizada em Washington, em setembro de 2000, que exigiram da OMS uma profunda revisão das bases conceituais e metodológicas do estudo, antes de uma eventual nova avaliação de desempenho dos sistemas de saúde dos países membros.

Claudia Travassos

Centro de Informação Científica e Tecnológica, Fundação Oswaldo Cruz

Paulo M. Buss

Escola Nacional de Saúde Pública, Fundação Oswaldo Cruz 
The controversial World Health Organization report

The World Health Report 2000 - Health Systems: Improving Performance, published by the World Health Organization (WHO), classifies the Organization's 191 member countries based on a new compound index called "overall health system performance" developed to monitor health sector reform processes in the respective countries. The index is a weighted mean of indicators aimed at measuring results related to the population's level of health, i.e., "disability-adjusted life expectancy at birth - DALE", non-medical aspects of health services provision, or "responsiveness", and "fairness of financial contribution".

To evaluate health systems is not a simple task, especially when the objective is to compare highly diverse realities, as the health systems of WHO member countries. The WHO's recent contribution to this field is open to criticism. The Organization used a new and complex performance index, but it was developed behind closed doors, not shared with the member countries, and its conceptual and methodological parameters were not even made public or accessible until the Report's results were published. The Report is referenced on a particular health system model, questioning universalist health policies, whose effectiveness it considers limited. This approach diverges from the orientation of various health systems, specifically that adopted by the Brazilian Unified Health System (SUS), based on the principle of universal access to health services.

Criticism of the WHO evaluation becomes even more serious when one analyzes in detail the methodology used to construct the index. What follows are critiques by researchers from the Oswaldo Cruz Foundation (FIOCRUZ) (for further details see their report at http://www.ensp.fiocruz.br/deptos/cedoc/Informe/textos/omsfinal.rtf).

Health inequalities were calculated by means of a formula measuring differences between individuals in relation to mean DALE in the population. Thus, the formula may detect differences, but it is incapable of indicating which social groups display the worst health conditions, thus limiting its ability to guide policy-making. Furthermore, in addition to the inherent difficulty in measuring DALE, for many member countries it was measured on the basis of socioeconomic variables. Thus, the WHO approach focused on social inequalities associated with health conditions, but failed to take into account the equity that can result from health system functioning per se. In reality, the compound index does not measure whether the population has its health needs met, since it fails to include any indicator of health services utilization. Thus, a country can show a good performance as measured by the index, while displaying marked inequalities in the utilization and quality of health services.

Assessment of "responsiveness" was based on evaluations by qualified informants in only 35 countries, then used to estimate the indicator in other countries, thus raising doubts as to the validity of this indicator. Measuring fairness in family share of financing the health system was also limited in its capacity to grasp the respective countries' specificities. In the Brazilian case, potentially progressive taxes were not included.

What might have been a contribution and incentive to the improvement of the member countries' health systems ended up in discredit towards the study's objectives and disavowal by various countries towards the strategies adopted in drafting the $2000 \mathrm{Re}$ port. This same understanding was expressed by the Ministers of Health of the Americas at the 42nd Meeting of the Board of the Pan-American Health Organization in Washington in September 2000, who demanded that the WHO conduct an in-depth review of the study's conceptual and methodological parameters before a new evaluation of health systems performance in member countries.

Claudia Travassos

Centro de Informação Científica e Tecnológica, Fundação Oswaldo Cruz

Paulo M. Buss

Escola Nacional de Saúde Pública, Fundação Oswaldo Cruz 